\title{
Meat Quality of Chicken Breast Subjected to Different Thawing Methods
}

http://dx.doi.org/10.1590/1516-635x1702165-172

\section{-Author(s)}

\section{Oliveira MR}

Gubert G"

Roman SS"

Kempka APIII

Prestes RCIV

Federal University of Santa Maria (UFSM), Academy of advanced level course in Food Technology, Santa Maria, RS, Brazil.

" Universidade Regional Integrada do Alto Uruguai e das Missões (URI), Department of Health Sciences, Erechim, Rio Grande do Sul, Brazil.

III State University of Santa Catarina (UDESC) Department of Food Engineering, Pinhalzinho, SC, Brazil.

Iv Federal University of Santa Maria, Department of Technology and Food Science, Graduate Program in Food Science and Technology (PPGCTA), Santa Maria, RS, Brazil.

\section{ABSTRACT}

Freezing is one of the methods to preserve and guarantee the quality of meat until it reaches the consumer. Even though freezing is classified as a mild form of preservation, it causes meat changes resulting from the formation of ice crystals that subsequently affect the tenderness and functionality of meat. The aim of this study was to evaluate the physicochemical and structural characteristics of chicken half breast submitted to fast freezing $\left(-36^{\circ} \mathrm{C}\right.$ for 2 hours) and thawed by five different methods (under refrigeration, in a microwave, in a oven with air circulation, placed in cold water, or at room temperature). After thawing, the following parameters were evaluated: moisture content, drip loss (syneresis), water activity $\left(a_{w}\right)$, and shear force. Samples were also histologically evaluated by light microscopy. The results indicated that, despite being submitted to fast freezing, thawing affected ( $p$ $<0.05)$ most of the physicochemical and structural properties of the meat, except for $a_{w}$. Thawing in cold water (packed in low-density polyethylene bags and placed in cold water at approximately $10^{\circ} \mathrm{C}$ for 2 hours and 15 minutes) presented the best results due to lesser damage to the cell structure, as shown by the lower drip loss, higher moisture content, and greater tenderness of the samples compared to those thawed using the other methods. Histological examination showed that muscle fiber structural features and organization were maintained. Thawing at low temperatures seems to cause less damage to the meat structure and allows maintaining of its properties. It was concluded that the meat quality is not related only with the freezing method, but also with the method and conditions used in thawing.

\section{INTRODUCTION}

Freezing is one of the methods of preserving meat and guaranteeing its quality until it reaches the consumer (Xia et al., 2012). The main objectives of this preservation method is to inhibit microbial growth and delay metabolic activities. It allows maintaining almost all product characteristics of products and to stock them for long periods (He et al., 2013). Despite being one of the least aggressive preservation methods, freezing still produces modifications in foods and the magnitude of these changes is directly related to the speed of freezing.

Food texture is modified by freezing due to the denaturation and aggregation of proteins (Damoradan et al., 2010) caused by the formation and growth of ice crystals and by processes associated with dehydration and the concentration of solutes in the muscle tissue. In addition of losing water, thawed meat loses other functional properties, such as water-holding capacity (WHC) and proteins, which may impair the gelling of the final product that contains this raw material(Olivo \& Olivo, 2006; He et al., 2013; Xia et al., 2012). 
Depending on its speed, the freezing process can be classified as slow or fast (Silva, 2000). In slow freezing, products are frozen at $0.05^{\circ} \mathrm{C} / \mathrm{min}$, whereas in fast freezing, the rate applied is $0.5^{\circ} \mathrm{C} / \mathrm{min}$. Fast freezing produces the formation of small ice crystals that are uniformly distributed both within and outside the muscle cells. Slow freezing favors the formation of large ice crystals at smaller quantities in the extracellular region, causing lesser damage to cells (Fellows, 2006; Damoradan et al., 2010).

However, in order to ensure the quality of the final product, appropriate thawing methods also need to be considered. There are several methods to thaw meat, but in general, it is generally recommended that pieces of meat should preferably be thawed slowly and at low temperatures (Ordoñez et al., 2005). According to Colla \& Prentice-Hernández (2003), during this process, water slowly returns to its original position in the tissues prior to freezing, and the repositioning of protein is more complete when defrosting is performed slowly at low temperatures.

Different thawing methods, such as using cold air circulation (cold storage or home refrigerators), slightly warmed air (heater) in a microwave oven, immersion in cold water, or room temperature (He et al., 2013; Xia et al., 2012). In recent years, high voltage electrostatic technology has been used for fast food thawing (He et al., 2013; He et al., 2014). These processes may affect the final characteristics of the product. It is also possible to thaw meat at relatively high temperatures, such as in ovens or at room temperature, but these methods apply temperatures between 20 and $30^{\circ} \mathrm{C}$, which may can contribute for microbial growth and increase drip loss, making meat unacceptable for human consumption.

Despite the previously mentioned factors, there is a gap in the literature reporting research on the evaluation of thawing methods and their effects on food. The Brazilian legal standard, CVS-6/99, of the National Agency for Health Surveillance (ANVISA), states that thawing should be performed at temperatures up to $4{ }^{\circ} \mathrm{C}$ or under controlled conditions (BRASIL, 1999). In addition, the Brazilian Ministry of Agriculture (MAPA) establishes in the Regulation of Industrial and Health Inspection of Animal Products (RIISPOA) that fish that has been thawed cannot be re-frozen in freezing chambers (BRASIL, 1952). Ordinance 711 (11/01/95) of MAPA determines that pork must be thawed should be performed in appropriate cold storage chambers at $5^{\circ} \mathrm{C}$ and with air speed of 2-3 m/sec (BRASIL, 1995). However, there are no parameters established for other methods of thawing, the use of microwave ovens or tumblers. Unfortunately, many consumers thaw meat at room temperature, which poses great health risks and impairs product quality.

This study aimed at evaluating the influence of five thawing methods on the physicochemical and structural characteristics of chicken half breast subjected to fast freezing $\left(-36^{\circ} \mathrm{C}\right.$ for 2 hours).

\section{MATERIALS AND METHODS}

The experiments were performed at the laboratories of the Federal University of Santa Maria (UFSM), Santa Maria, RS, Brazil. Microscopy was performed in the histology laboratory of the Department of Pharmacy of the Integrated Regional University of Alto Uruguai e das Missões (URI). One hundred and twenty five samples (twenty-five samples per treatment) of chicken half breast (pectoralis major), weighing approximately $250 \mathrm{~g}$ each were donated by the cooperative Aurora (Quilombo, SC, Brazil). Samples were individually frozen in the processing plant (fast freezing to -36 ${ }^{\circ} \mathrm{C}$ in 2 hours) and kept under freezing temperatures $\left(-18^{\circ} \mathrm{C}\right)$ until analysis. Five different thawing methods were evaluated: $\mathrm{M} 1$ (under refrigeration in a domestic refrigerator at around $7{ }^{\circ} \mathrm{C}$ for 22 hours); $\mathrm{M} 2$ (in a microwave oven for 6 minutes); M3 (in an electric oven with air circulation at approximately $40{ }^{\circ} \mathrm{C}$ for 2 hours and 15 minutes); M4 (packed in low-density polyethylene bags and placed in cold water of around $10^{\circ} \mathrm{C}$ for 2 hours and 15 minutes); and M5 (at room temperature of approximately $17^{\circ} \mathrm{C}$ for 2 hours and 20 minutes). Thawing was terminated when deep muscle temperature reached $10{ }^{\circ} \mathrm{C}$ in all methods. A microwave oven (PHILCO, Model PMS 35N, Curitiba, PR, Brazil) and an electric oven with air circulation (ALPAX, model 400-4ND, Diadema, SP, Brazil) were used.

After thawing, the following parameters were determined: moisture content (\%), drip loss (syneresis) $(\%)$, shear force $\left(\mathrm{kgf} \mathrm{cm}^{-2}\right)$, and water activity $\left(\mathrm{a}_{\mathrm{w}}\right)$. Moisture content was determined according to official methods (AOAC, 1990; IAL, 2005).

Drip loss was determined by weighing the samples on a semi-analytical scale (MARTE, Model AS2000C, São Paulo, SP, Brazil) before and after thawing, and calculated as the difference between initial and final weight, and expressed in percentage, according to a modification of the method of Northchutt et al., 1994. The method of Northchutt et al. (1994) consists in simulating retail conditions, i.e., cuts are stored 
at about $3{ }^{\circ} \mathrm{C}$ for $72 \mathrm{~h}$, after which weight loss is determined. The modification consisted in quantifying drip loss immediately after thawing.

Shear force was measured using a TA-XT.plus texturometer, and the obtained results were analyzed using a specific software (Stable Microsystems Ltd., Surrey, UK). After thawing, samples were cooked in an oven at $180^{\circ} \mathrm{C}$ until $72^{\circ} \mathrm{C}$ internal temperature was achieved and then cooled to $18^{\circ} \mathrm{C}$, cut (3-cm wide, $1-\mathrm{cm}$ thick, and $2.5-\mathrm{cm}$ long) and subjected to texture analysis using the mentioned equipment. Water activity $\left(a_{w}\right)$ was determined in a duly calibrated water-activity meter (Aqualab ${ }^{\circledR}$, Series 4TE, Decagon, USA) unit.

Meat samples were also submitted histological evaluation under light microscopy. Three fragments were removed from one sample per treatment corresponding to the center of the chicken half breast. The collected material was processed according to the conventional technique described by Junqueira \& Carneiro (2008). Samples were qualitatively evaluated relative to the presence of collagen and muscle fibers, fat, fibrous and compact tissue, swelling, cytoplasmic vacuoles, disruption, muscle degeneration, disorganization, and cytoplasmic muscle striation (precursor of edema). Three slides were prepared per treatment. Samples were cut into 4- $\mu$ m thick sections and then stained with hematoxylin and eosin. Slides were examined under a light microscope (Leica Microscopy Systems, Heerbrugg, Switzerland) and the software Motic Images Plus 2.0 (Motic Instruments, Inc., Richmond, Canada) was used to capture images.

A completely randomized experimental design was applied, with three replicates per treatment. The results were submitted to analysis of variance (ANOVA) and means were compared by the test of Tukey at $95 \%$ significance level $(p<0.05)$ using the statistical package Statistica ${ }^{\circledR} 9.0$ (STATSOFT, INC).

\section{RESULTS AND DISCUSSION}

All the evaluated parameters were influenced by the treatments $(p<0.05)$, except for $A_{w}$ (Table 1$)$. In general, the best results were found for method M4.

Drip loss ranged from $1.27 \%(\mathrm{M} 4)$ to $7.65 \%(\mathrm{M} 2)$. Treatment M4 resulted in the lowest drip loss. This is an interesting result because the drip loss obtained with M4 was lower than that observed with treatment M1, which was the most frequently recommended treatment. The highest drip loss was detected in M2 samples (thawed in a microwave oven) possibly due to greater protein denaturation, which increases water loss. According to Olivo \& Olivo (2006), in addition to losing moisture, thawed meat loses functional properties, such as water retention ability and proteins, which may impair the gelling of final products containing meat.

These results are consistent with the findings of other studies. Pires et al. (2002) obtained drip loss values of 7.29 and 3.39 in pork samples thawed at $25^{\circ} \mathrm{C}$ and $7{ }^{\circ} \mathrm{C}$, respectively, while Pietrasik \& Janz (2009) observed 3.30\% drip loss in beef thawed at 4 ${ }^{\circ} \mathrm{C}$. Up to $18.27 \%$ drip loss was found in pork samples submitted to freezing-thawing (Xia et al., 2013). Drip loss increased $(2.10 \%$ to $10.25 \%)$ when pork steaks were frozen and thawed and then stored (at $1.0^{\circ} \mathrm{C}$ for 7 days) (Kim et al., 2013).

In this experiment moisture content was reduced as a function of drip loss. Moisture content of the

Table 1 - Drip loss (\%), moisture content (\%), water activity $\left(A_{w}\right)$ and shear force $\left(\mathrm{kgf.cm}^{-2}\right)$ of chicken half breast samples subjected to different thawing methods.

\begin{tabular}{|c|c|c|c|c|c|}
\hline Treatments & M1 & M2 & M3 & M4 & M5 \\
\hline Drip loss (\%) & $\begin{array}{l}3.60^{b} \\
\pm 0.97\end{array}$ & $\begin{array}{r}7.65^{a} \\
\pm 0.97\end{array}$ & $\begin{array}{c}3.55^{b} \\
\pm 0.36\end{array}$ & $\begin{array}{r}1.27^{c} \\
\pm 0.52\end{array}$ & $\begin{array}{c}4.84^{b} \\
\pm 0.78\end{array}$ \\
\hline Moisture content (\%) & $\begin{array}{l}73.90^{\circ} \\
\pm 0.16\end{array}$ & $\begin{array}{l}73.97 \\
\pm 0.20\end{array}$ & $\begin{array}{l}75.03^{b} \\
\pm 0.33\end{array}$ & $\begin{array}{c}74.75^{b} \\
\pm 0.3\end{array}$ & $\begin{array}{r}75.92^{a} \\
\pm 0.18\end{array}$ \\
\hline$A_{w}$ & $\begin{array}{r}0.991^{\mathrm{a}} \\
\pm 0.001\end{array}$ & $\begin{array}{r}0.993^{a} \\
\pm 0.002\end{array}$ & $\begin{array}{r}0.993^{a} \\
\pm 0.002\end{array}$ & $\begin{array}{r}0.993^{a} \\
\pm 0.001\end{array}$ & $\begin{array}{r}0.992^{a} \\
\pm 0.002\end{array}$ \\
\hline Shear force $\left(\mathrm{kgf} . \mathrm{cm}^{-2}\right)$ & $\begin{array}{c}2.60^{b} \\
\pm 0.90\end{array}$ & $\begin{array}{c}3.20^{a} \\
\pm 0.85\end{array}$ & $\begin{array}{l}2.69 b c \\
\pm 0.95\end{array}$ & $\begin{array}{c}1.84^{c} \\
\pm 0.58\end{array}$ & $\begin{array}{l}2.58^{b c} \\
\pm 0.84\end{array}$ \\
\hline
\end{tabular}

* Means followed by different superscripts in the same row are significantly different $(p<0.05)$ by the test of Tukey.

** Treatments: M1 (thawing in a refrigerator); M2 (thawing in a microwave oven); M3 (thawing in an electric oven); M4 (thawing by immersion in water), and M5 (thawing at room temperature).

$* * * N=25$. 
samples evaluated in the present study ranged between $73.90 \%$ and $75.92 \%$, which values are higher than the $71 \%$ reported by Mounteney \& Parkhust (2001) and close to $74.76 \%$ mentioned by the USDA (2005) and Damoradan et al. (2010). Kim et al. (2013) showed that freezing-thawing of pork induced drip loss, and decreased moisture content, cooking loss, tenderness, lightness and redness of meat.. In contrast with the results found in the present study, Pires et al. (2002) did not observe any differences in moisture content for pork loin samples stored frozen for 15 days and thawed at $7^{\circ} \mathrm{C}$ or $25^{\circ} \mathrm{C}$.

Water activity $\left(a_{w}\right)$ was not affected ( $\left.p>0.05\right)$ by thawing methods. The water content has a strong influence on the physicochemical stability of foods during storage and distribution. The most common direct techniques are either desiccation or oven drying based. The most frequently used method is based on food mass loss during cooking an oven (Reh et al., 2004). Water activity is a thermodynamic concept used to characterize water content. It is measured by the ratio between water vapor pressure in the atmosphere in equilibrium with the material and the saturated vapor pressure of pure water at the same temperature. The control of $a_{w}$ involves the determination of free water in the food that is directly related with microbial growth (shelf life, aroma production, etc.) (Simatos et al., 2011). Despite the differences in moisture contents in drip loss among the different treatments, these variations did not reduce $a_{w}$.

The shear force obtained in the meat samples submitted to the different treatments ranged between 1.84 and $3.20 \mathrm{kgf} \mathrm{cm}^{-2}$, with the lowest shear strength found in M4 samples (thawing in water). This result may be correlated with the lower drip loss and higher humidity content of those samples, indicating less protein damage, and consequently the meat was more tender and juicier. On the other hand, treatment M2 samples (thawing in a microwave oven) presented the highest shear force, which may be explained by their higher drip loss and lower moisture content. Frozen and thawed meat tends to have higher shear strength than fresh meat, which may be due to fiber shrinkage and drip loss. Xia et al. (2009) reported that the cutting force of pork increases after one freezing-thawing cycle compared to that of fresh pork. In contrast with the findings in the present study, Pires et al. (2002) did not find any differences in the texture of pork loin thawed at $25^{\circ} \mathrm{C}$ or at $7{ }^{\circ} \mathrm{C}$. Pietrasik \& Janz (2009) evaluated fresh and frozen/thawed beef samples and observed that the samples thawed at $4^{\circ} \mathrm{C}$ lost more weight and were tougher $(40.00 \mathrm{~N})$ than the fresh meat samples $(35.40 \mathrm{~N})$ and concluded that freezing/ drying increased meat toughness. Pires et al. (2002) evaluated the tenderness and weight loss of pork loin (Longissimus dorsi) subjected to different freezing and thawing methods. Samples were thawed at $7{ }^{\circ} \mathrm{C}$ or at $25^{\circ} \mathrm{C}$. The results indicated that tenderness was not affected by the treatments and that the thawing temperature of $25^{\circ} \mathrm{C}$ caused greater weight loss than thawing at $7{ }^{\circ} \mathrm{C}$. The authors suggested that thawing should be carried out undercooling.

One of the main problems caused by meat thawing and cooking is the excessive release of liquid and consequently, nutrient loss, damaging processing profitability and deceiving consumers. Moreover, the thawing process should be controlled because temperature increase promotes the growth of microorganisms present in the meat, posing foodpoisoning risks and increasing product spoilage. Inadequate thawing of frozen meat causes significant quality deterioration, due to the formation of large extracellular ice crystals, lipid oxidation, protein oxidation, protein denaturation, and microbial growth during thawing (Xia et al., 2012). In the study of Colpo et al. (2012), chicken breast thawed under refrigeration compared with thawing in a microwave oven and at room temperature presented the best meat-quality results, as shown by less product damage, as suggested by Colla \& Prentice-Hernández (2003). When thawed in a refrigerator $\left(4^{\circ} \mathrm{C}\right)$ pork samples presented physicochemical characteristics closest to fresh samples and the least quality losses compared with other thawing methods (room temperature, water immersion, or in a microwave oven) (Xia et al., 2012).

Collagen and muscle fibers, fat, fibrous and compact tissue, swelling, cytoplasmic vacuoles, disruption, muscle degeneration and disorganization, and cytoplasmic muscle striation (precursor of edema) were evaluated by histology (Figure 1).

The evaluated thawing methods had different effects on the meat structure. Photomicrographs $A$ and $B$ refer to the treatment of thawing by water immersion, $C$ and $D$ correspond to thawing under refrigeration, $E$ and $F$ correspond to thawing in the microwave oven, $\mathrm{G}$ and $\mathrm{H}$ correspond to thawing in the electric oven, and finally, I and J correspond to thawing at room temperature. Photomicrographs $A$ and $B, E$ and $F, G$ and $H$ show the meat structure presented less alterations and similar appearance to normal muscle fibers. Photomicrographs $C$ and $D$ and 

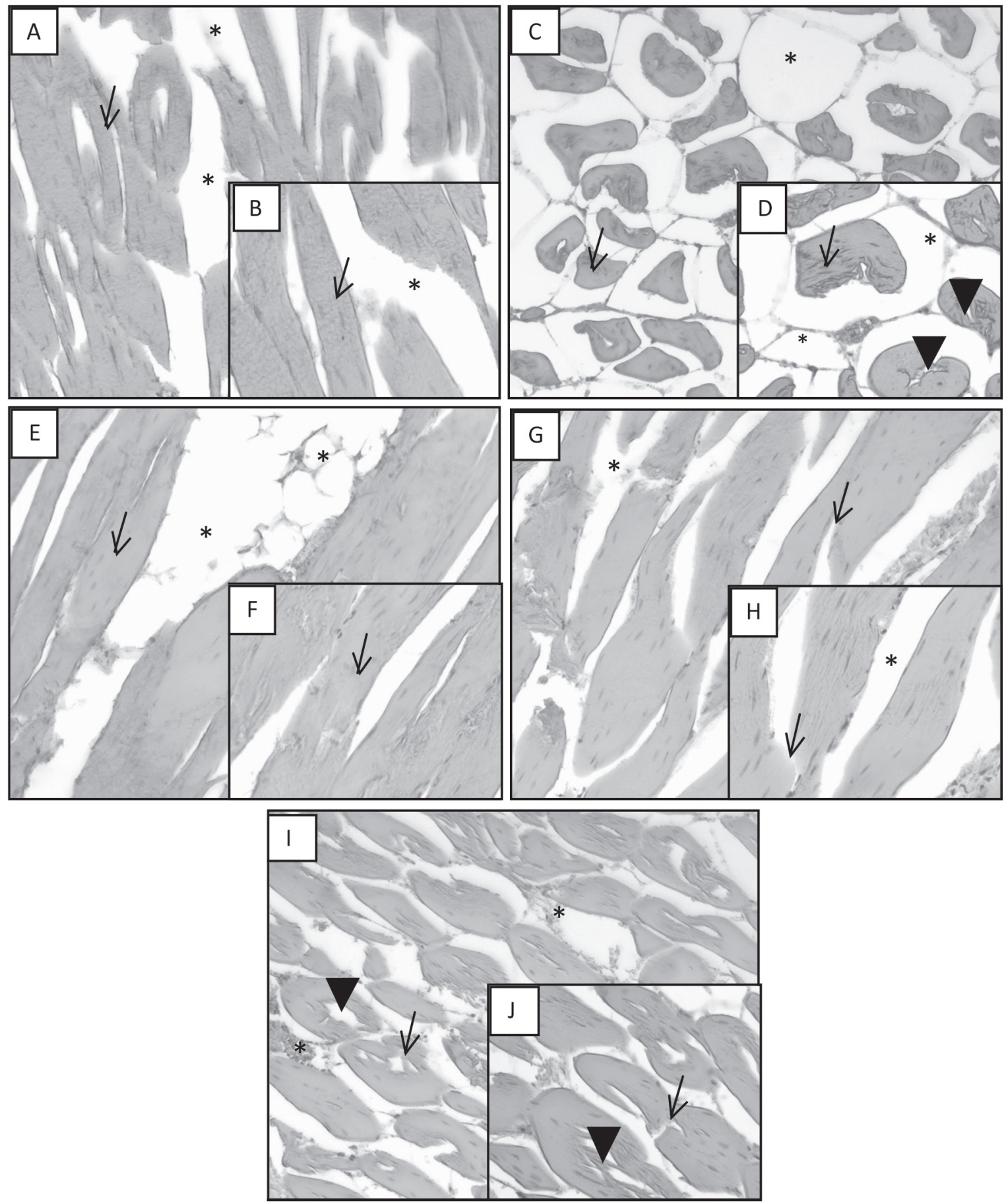

Figure 1 - Photomicrographs of the longitudinal sections of chicken muscle fibers exposed to different thawing methods. B (detail of A, treatment M4): note the presence of a large extracellular space ${ }^{*}$ ) between the skeletal muscle fibers with reduced size (arrows). D (detail of C, treatment M1): short muscle cells presenting cytoplasm striations (arrows) and intracellular edema (arrowheads), and the presence of interstitial adipose tissue $\left(^{*}\right)$. F (detail of $E$, treatment M2): intact and well-organized muscle fiber with normal appearance (arrows) and the presence of interstitial adipose tissue $\left({ }^{*}\right)$. $\mathrm{H}$ (detail of $\mathrm{G}$, treatment $\mathrm{M} 3$ ): note the muscle fibers with little disorganization and very similar to normal cells (arrows), and the extracellular space $\left(^{*}\right)$. J (detail of I, treatment M5): substantial muscle breakdown and intracellular edema (arrowheads), cytoplasmic striations and irregularities in the cell periphery (arrows), degeneration in the muscle fiber $\left({ }^{*}\right)$.

** Treatments: M1 (thawing in a refrigerator); M2 (thawing in a microwave oven); M3 (thawing in an electric oven); M4 (thawing by immersion in water), and M5 (thawing at room temperature). 
I and J show extensive changes and substantial muscle damage resulting from water crystallization and the growth and expansion of intracellular and extracellular ice crystals. The images show regions where the ice crystals were possibly deposited during freezing, leading to structural changes such as fiber separation, intracellular gaps, and the release of cell material.

Meat samples submitted to treatments M4 (thawing by water immersion), M2 (thawing in a microwave oven), and M3 (thawing in an electric oven) showed well-organized, almost normal muscular structures. On the other hand, M1 (thawing in a refrigerator) and M5 (thawing at room temperature) samples presented considerable muscle breakdown, with intracellular edema, cytoplasmic striations (which did not match myofibrillar striations, but corresponded to muscle damage), and irregularities in the cell periphery, and therefore significant degeneration of muscle fiber. Ambrosiadis et al. (1994) reported that fast thawing by water immersion decreased drip loss, whereas thawing in a microwave oven for $35 \mathrm{~min}$ until $0^{\circ} \mathrm{C}$ showed higher drip losses.

The formation of ice crystals during freezing leads to structural damage due to the concentration of solutes in the meat, which, in turn, leads to changes in the biochemical reactions that occur at cell level and influence the physical parameters of the meat. Large extracellular ice crystals disrupt the muscle physical structure, breaking and separating the myofibrils, while the formation of small ice crystals results in lesser intracellular damage. Freezing and thawing may alter both water content and distribution in meat tissues because these release the water that is immobilized and linked to protein in the intracellular spaces (Leygonie et al., 2012). However, in order to return as closely as possible to its fresh state, the water in meat that is released by thawing should be redistributed to the extracellular and sarcoplasmic spaces. Franco (2007) also observed damage caused by ice crystals in histological sections of chicken breast (Pectoralis major) and the influence of temperature on the functional properties of the meat. Xia et al. (2012) evaluated muscle microstructural and showed that microwave thawing visibly induced larger gaps between muscle fibers and tore more muscle fiber bundles compared with other thawing methods (room temperature, water immersion, or in a refrigerator).

The results of the present study indicate that, although samples were subjected to rapid freezing ($36{ }^{\circ} \mathrm{C}$ for 2 hours), the evaluated thawing methods significantly affected most of the physicochemical and structural properties of the meat. The M4 treatment (thawing of meat packed in low-density polyethylene bags immersed in cold water at approximately $10{ }^{\circ} \mathrm{C}$ for 2 hours and 15 minutes) was the method that yielded the best results due to lesser damage to the cell structure, resulting in lower drip loss, high moisture content, and greater tenderness. These results agree with those of Ambrosiadis et al. (1994), who found that fast thawing by water immersion reduced meat quality loesses.

\section{CONCLUSIONS}

All the evaluated thawing methods affected meat characteristics and the chicken half breast samples thawed by immersion in cold water presented the lowest drip loss, greater tenderness and the maintenance of the structural features and organization of the muscle fibers. The results indicated that, although samples were subjected to fast freezing, thawing affected most of the physicochemical and structural properties of the meat, except for $A_{w}$. Thawing by immersion in cold water (samples packed in low-density polyethylene bags and immersed in cold water at approximately $10^{\circ} \mathrm{C}$ for 2 hours and 15 minutes) was the method that presented the best results due to less cell structure damage, resulting in lower drip loss, high moisture content, and greater tenderness. The histological evaluation of these samples showed that the structural features and organization of its muscle fibers were maintained. Thawing at low temperatures seems to cause less damage to the meat structure of the meat and allows maintaining its properties. It was concluded that meat quality is related not only with the freezing method applied, but also with thawing methods and conditions.

\section{REFERENCES}

Ambrosiadis I, Theodorakakos N, Georakis S, Lekas S. Influence of thawing methods on the quality of frozen meat and drip loss. Fleischwirtschaft $1994 ; 74: 284-286$

AOAC. Official Methods of Analysis of the Association of Analytical Chemists. 40 ${ }^{\text {th }}$ ed. Washington; 1990.

BRASIL. Ministério da Agricultura, Pecuária e Abastecimento. Lei n. 1283, de 18 de dezembro de 1950 e Decreto $n^{\circ}$. 30.691, de 29 de março de 1952. Regulamento de Inspeção Industrial e Sanitária de Produtos de Origem Animal (RIISPOA). Brasília, DF; 1952.

BRASIL. Ministério da Agricultura, Pecuária e Abastecimento. Portaria Nº 711, de 01 de novembro de 1995. Aprova as normas técnicas de instalações e equipamentos para abate e industrialização de suínos. Diário Oficial da União, Brasília, DF, 3 nov.1995.

BRASIL. Ministério da Saúde. Agência Nacional de Vigilância Sanitária. Portaria CVS-6/99, de 10 de março de 1999. Regulamento Técnico 
que estabelece os Parâmetros e Critérios para o Controle HigiêncioSanitário em Estabelecimento de Alimentos, Brasília, Ministério da Saúde, 1999.

Colla LM, Prentice-Hernández C. Congelamento e descongelamento - sua influencia sobre os alimentos. Revista Vetor 2003;13:53-66.

Colpo H, Prestes RC, Fazolo R, Kempka AP. Influência de diferentes métodos de descongelamento na qualidade de peito de frango. Revista Nacional da Carne 2012;2(425):66-72.

Damoradan S, Parkin KL, Fennema OR. Química de alimentos de Fennema. $4^{\mathrm{a} e d .}$. Porto Alegre: Artmed; 2010

Fellow PJ. Tecnologia do processamento de alimentos: princípios e práticas. $2^{\mathrm{a} e d}$. Porto Alegre: Artmed; 2006.

Franco FO. Efeito das variações térmicas na perda de umidade em carcaças de frango [dissertation]. São Paulo (SP): Universidade de São Paulo; 2007.

He $X$, Tatsumi E, Nirasawa S, Liu H. Factors affecting the thawing characteristics and energy consumption of frozen pork tenderloin meat using high-voltage electrostatic field. Innovative Food Science and Emerging Technologies 2014;22:110-115.

He X, Liu R, Nirasawa S, Zheng D, Liu H. Effect of high voltage electrostatic field treatment on thawing characteristics and post-thawing quality of frozen pork tenderloin meat. Journal of Food Engineering 2013; 115:245-250.

Instituto Adolfo Lutz. Agência Nacional de Vigilância Sanitária. Métodos físico-químicos para análises de alimentos. Brasília: Ministério da Saúde, Agência Nacional de Vigilância Sanitária; 2005.

Junqueira LC, Carneiro J. Histologia básica. $11^{\text {th }}$ ed. São Paulo: Guanabara Koogan; 2008.

Kim G, Jung E, Kim H, Yang H, Joo S, Jeong J. Influence of meat exudates on the quality characteristics of fresh and freeze-thawed pork. Meat Science 2013;95:323-329.

Leygonie C, Britz TJ, Hoffman LC. Impact of freezing and thawing on the quality of meat: Review. Meat Science 2012;91:93-98.
Mountney GJ, Parkhust CR. Tecnología de productos avícolas. Zarogoza: Acribia; 2001.

Northcutt JK, Foegeding EA, Edens FW. Walter-holding propertiesof thermally preconditioned chicken breast and leg meat. Poultry Science 1994;73:308-316.

Olivo R, Olivo N. O mundo das carnes:ciência, tecnologia \& mercado. Criciúma: Ed do Autor; 2006.

Ordóñez JAP, coordenador. Tecnologia de alimentos. Porto Alegre: Artmed; 2005.

Pietrasik Z, Janz JAM. Influence of freezing and thawing on the hydration characteristics, quality, and consumer acceptance of whole muscle beef injected with solutions of salt and phosphate. Meat Science 2009;81:523-532.

Pires ISC, Rosado GP, Azeredo RMC, Neves MB, Miranda LS. Composição centesimal, perdas de peso e maciez de lombo (Longissimus dorsi) suíno submetido a diferentes tratamentos de congelamento e descongelamento. Revista de Nutrição 2002;15(2):163-172.

Reh C, Shirinivasa NB, Berrut S. Determination of water content in powdered milk. Food Chemistry 2004;86(3):457-464.

Silva JA. Tópicos da tecnologia dos alimentos. São Paulo: Varela; 2000.

Simatos D, Roudaut G, Champion D. Water in dairy products - analysis and measurement of water activity. Oxford: Academic Press; 2011.

USDA. Composition of Foods Raw, Processed, Prepared. USDA, Released 18. 2005. Available from: http://www.nal.usda.gov/fnic/foodcomp/.

Xia X, Kong B, Liu Q, Liu J. Physicochemical change and protein oxidation in porcine Longissimus dorsi as influenced by different freeze-thaw cycles. Meat Science 2009;83:239-245.

Xia X, Kong B, Liu J, Diao X, Liu Q. Influence of different thawing methods on physicochemical changes and protein oxidation of porcine longissimus muscle. LWT- Food Science and Technology 2012;46:280-286. 
